Brit. J. industr. Med., 1956, 13, 41.

\title{
THE ACTION OF VARIABLE AMOUNTS OF TRIDYMITE, AND OF TRIDYMITE COMBINED WITH COAL, ON THE LUNGS OF RATS
}

\author{
BY \\ DAPHNE ATTYGALLE, E. J. KING, and C. V. HARRISON \\ From the Postgraduate Medical School of London \\ AND \\ G. NAGELSCHMIDT \\ From the Safety in Mines Research Establishment, Sheffield
}

(RECEIVED FOR PUBLICATION JUNE 24, 1955)

It was first shown by Gardner (1938a and b) in animal experiments that tridymite appeared to be more fibrogenic than quartz when tested by intravenous injection in rabbits. In fact, all his animals injected with tridymite died by 11 weeks. King, Mohanty, Harrison, and Nagelschmidt (1953a) used intratracheal injections into the lungs of rats, and compared well graded pure samples of quartz and tridymite, with the result that tridymite produced grade 5 fibrosis after nine weeks as against 38 weeks for quartz. The tridymite sample used had been in contact with hydrofluoric acid during purification, and as it had been found in other experiments (King and others, 1953b) that quartz etched with hydrofluoric acid also was more fibrogenic than normal quartz, there remained a suspicion that a trace of hydrofluoric acid had been the cause of the extra activity of tridymite.

A new series of experiments was therefore set up with another sample of tridymite which had never been in contact with hydrofluoric acid. This sample was used at three different levels of dosage $(12 \cdot 5,25$, and $50 \mathrm{mg}$. per rat), and electro-dialyzed tridymite which was free from any adsorbed ions was also used at the $25 \mathrm{mg}$. per rat level.

The fibrogenic activity of quartz and other materials has in the past been expressed solely on the basis of the degree of maturity of the lesions and the following five grades of fibrosis were used : grade 1 , loose reticulin fibres with no collagen formation ; grade 2, compact reticulin fibres with or without collagen formation; grade 3 , slightly cellular but mostly collagenous; grade 4, wholly collagenous and completely acellular ; and grade 5, acellular, collagenous and confluent.
It has been felt for some time that this was not entirely satisfactory for quantitative assessments because the amount as well as the degree of fibrosis should be measured. Various attempts at an area assessment from microscope slides, and to use radiography of air-inflated rats' lungs, did not prove successful, but a quantitative estimation of collagen (Stacy and King, 1954) from dried lung material proved to be possible, and this technique was used to measure the fibrogenic activity of tridymite. Similar data for quartz were available, and this allowed equal dosages of quartz and tridymite to be compared.

It had been found previously (Ray, King, and Harrison, 1951) that $2 \mathrm{mg}$. of quartz did not produce any fibrosis in the lungs of rats, but did produce fibrosis of the lymph nodes, into which all of it appeared to have been moved, when given alone. A mixture of $2 \mathrm{mg}$. of quartz and $98 \mathrm{mg}$. of coal did, however, produce fibrosis up to grade 2 after five months in the lungs of rats. Similar experiments with smaller amounts of dust were also made with tridymite and two samples of coal.

\section{DESCRIPTION OF SAMPLES Tridymite}

This was prepared from Lochaline sand by the use of a flux. The flux was dissolved after heating by prolonged boiling with hydrochloric acid. The resulting tridymite was very pure, and a fraction below $2 \mu$ was prepared by sedimentation in water after grinding the material in an agate mortar. Part of the tridymite was electro-dialyzed for $\mathbf{2 4}$ hours between platinum electrodes to remove any adsorbed electrolyte. The chemical analysis, solubilities, and particle size distribution of the two samples of tridymite are given in Table 1. 
TABLE 1

PARTICLE SIZE DISTRIBUTION AND ANALYSIS OF SAMPLES OF TRIDYMITE

\begin{tabular}{|c|c|c|c|c|}
\hline Sample & \multicolumn{2}{|c|}{ Tridymite } & \multicolumn{2}{|c|}{$\begin{array}{l}\text { Electro-dialyzed } \\
\text { Tridymite }\end{array}$} \\
\hline \multirow{2}{*}{ Size in $\mu$} & \multicolumn{2}{|c|}{ Percentage } & \multicolumn{2}{|c|}{ Percentage } \\
\hline & By No. & By Mass & By No. & By Mass \\
\hline $\begin{array}{l}0.23-0.32 \\
0.32-0.45 \\
0.45-0.64 \\
0.64-0.9 \\
0.9-1 \cdot 3 \\
1 \cdot 3-1.8 \\
1.8-2.6 \\
2.6-3.6\end{array}$ & $\begin{array}{r}\overline{12.5} \\
22.4 \\
29.4 \\
27.3 \\
6.2 \\
1.6 \\
0.6\end{array}$ & $\begin{array}{r}\overline{0.7} \\
3.4 \\
12.3 \\
31.8 \\
20.7 \\
15 \cdot 0 \\
16.1\end{array}$ & $\begin{array}{r}22.4 \\
22.1 \\
18.4 \\
14 \cdot 1 \\
9.4 \\
7.8 \\
4.0 \\
1.8\end{array}$ & $\begin{array}{r}0 \cdot 3 \\
0 \cdot 9 \\
2 \cdot 1 \\
4 \cdot 4 \\
8 \cdot 3 \\
19 \cdot 6 \\
28 \cdot 2 \\
36 \cdot 2\end{array}$ \\
\hline 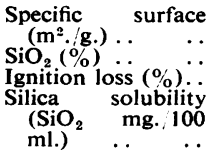 & \multicolumn{2}{|c|}{$\begin{array}{c}2 \cdot 3 \\
99 \cdot 3 \\
0 \cdot 10\end{array}$} & \multicolumn{2}{|c|}{$\begin{array}{c}1 \cdot 7 \\
99 \cdot 2 \\
0 \cdot 57\end{array}$} \\
\hline
\end{tabular}

Anthracite Coal

A low-ash fraction of anthracite coal from the Llandebie Colliery, South Wales, was turbine-ground and a fraction below $10 \mu$ separated by air elutriation with a Roller apparatus. From this material a fraction below $2 \mu$ was prepared by centrifuging in water after adding sufficient detergent (" teepol", Shell) to make the coal wettable. The material below $2 \mu$ equivalent diameter was spun down by prolonged centrifuging, boiled with water to remove as much of the "teepol" as possible, and finally dried. The particle size distribution and the analysis of this dust are given in Table 2.

TABLE 2

ANALYSIS AND PARTICLE SIZE DISTRIBUTION OF ANTHRACITE AND BITUMINOUS COAL

\begin{tabular}{|c|c|c|c|c|}
\hline \multirow{3}{*}{ Size in $\mu$} & \multirow{2}{*}{\multicolumn{2}{|c|}{$\frac{\text { Anthracite Coal }}{\text { Percentage }}$}} & \multirow{2}{*}{\multicolumn{2}{|c|}{$\frac{\text { Bituminous Coal }}{\text { Percentage }}$}} \\
\hline & & & & \\
\hline & By No. & By Mass & By No. & By Mass \\
\hline $\begin{array}{l}0.32-0.45 \\
0.45-0.64 \\
0.64-0.9 \\
0.9-1 \cdot 3 \\
1 \cdot 3-1 \cdot 8 \\
1.8-2 \cdot 6 \\
2 \cdot 6-3.6 \\
3 \cdot 6-5 \cdot 1 \\
5 \cdot 1-7 \cdot 2 \\
7 \cdot 2-10 \cdot 2\end{array}$ & $\begin{array}{r}7.55 \\
17.30 \\
20.71 \\
32.89 \\
9.26 \\
9.26 \\
1.46 \\
0.78 \\
0.61 \\
0.17\end{array}$ & $\begin{array}{c}0.08 \\
0.53 \\
1.75 \\
7.73 \\
6 \cdot 24 \\
17.47 \\
7.88 \\
11.71 \\
25.92 \\
20.68\end{array}$ & $\begin{array}{c}- \\
4 \cdot 4 \\
18 \cdot 7 \\
49 \cdot 4 \\
23 \cdot 9 \\
3 \cdot 3 \\
0 \cdot 3 \\
- \\
-\end{array}$ & $\begin{array}{c}\overline{0.37} \\
4.26 \\
31.2 \\
43.4 \\
16.76 \\
3.99 \\
- \\
-\end{array}$ \\
\hline $\begin{array}{l}\begin{array}{l}\text { Specific surface } \\
\left(\mathrm{m}^{2} \cdot / \mathrm{g} .\right) \ldots\end{array} \\
\text { Silica content }(\%)\end{array}$ & \multicolumn{2}{|c|}{$\begin{array}{l}1.9 \\
1.4\end{array}$} & \multicolumn{2}{|c|}{$\begin{array}{l}3.9 \\
1.05\end{array}$} \\
\hline
\end{tabular}

Bituminous Coal

A sample of bituminous dust below $2 \mu$ diameter was prepared by applying the same technique to a sample of bituminous coal from the Haig Pit, Cumberland. Its size distribution and analysis are also given in Table 2 .

\section{PREPARATION OF DUST SUSPENSIONS}

\section{Tridymite}

In order to give in $1 \mathrm{ml}$. of suspension $12.5 \mathrm{mg}$., 25 mg., and $50 \mathrm{mg}$. of tridymite, the following amounts were weighed out and shaken with $15 \mathrm{ml}$. of sterile physiological saline in $25 \mathrm{ml}$. screw-capped bottles : $0.1875 \mathrm{~g} ., 0.375 \mathrm{~g}$., and $0.75 \mathrm{~g}$. of the tridymite (and $0.375 \mathrm{~g}$. of the electro-dialyzed tridymite to give $25 \mathrm{mg}$. in $1 \mathrm{ml}$.). The mixtures were thoroughly shaken for $30 \mathrm{~min}$. in an electric shaking machine, autoclaved for $20 \mathrm{~min}$. at $15 \mathrm{lb}$. pressure, and then re-shaken until the time of the injection.

\section{Anthracite and Bituminous Coal}

Amounts of $0.75 \mathrm{~g}$. anthracite and bituminous coal were weighed and transferred into screw-capped bottles, and $24 \mathrm{ml}$. sterile physiological saline added to each. The suspensions were thoroughly shaken for half an hour, autoclaved for $20 \mathrm{~min}$. at $15 \mathrm{lb}$. pressure, and $1 \mathrm{ml}$. sterile rat serum added to each bottle of suspension to help to disperse and suspend the particles. The final concentration of dust was $30 \mathrm{mg}$. $/ \mathrm{ml}$.

\section{Anthracite and Bituminous Coal + Tridymite}

Samples each of $0.75 \mathrm{~g}$. of anthracite and of bituminous coal were weighed, and each was mixed intimately with $0.025 \mathrm{~g}$. of tridymite. The anthracitetridymite and bituminous-tridymite mixtures were made up as above with $24 \mathrm{ml}$. sterile saline and $1 \mathrm{ml}$. sterile rat serum. The final concentrations were thus $30 \mathrm{mg}$. anthracite or bituminous coal and $1 \mathrm{mg}$. tridymite/ $1 \mathrm{ml}$. of suspension.

\section{Tridymite (Control for Coal-tridymite Mixtures)}

A suspension of $1 \mathrm{mg}$. tridymite $/ \mathrm{ml}$. of saline was made up by shaking $25 \mathrm{mg}$. of tridymite with $25 \mathrm{ml}$. of saline as above.

\section{ANIMALS}

The black and white hooded strain of the Medical Research Council was used. They were male rats of average weight $250 \mathrm{~g}$. Ten animals were used in each of the four experiments on tridymite, and 18 were used in each of the five groups with anthracite, bituminous coal, anthracite + tridymite, bituminous + tridymite, and tridymite.

\section{EXPERIMENTAL PROCEDURE}

The rats were lightly anaesthetized with ether, the tongue was retracted forward with a small clip and an auroscope fitted with a medium-sized speculum was inserted into the mouth as far as the auropharynx. The throat was cleaned with a swab and a long, blunt needle $(10 \mathrm{~cm} . \times 14$ gauge) was passed between the vocal cords into the trachea until it struck the carina, and then it was slightly withdrawn about $2 \mathrm{~mm}$. ; $1.1 \mathrm{ml}$. of dust suspension (about $0.1 \mathrm{ml}$. usually remains in the long needle and syringe after the injection) was drawn into a $2 \mathrm{ml}$. syringe from the screw-capped bottles which were kept agitated in a mechanical shaker. The syringe was attached to the long needle and the suspension with $1 \mathrm{ml}$. of air was quickly and forcibly injected. The needle was withdrawn from the trachea. The animals suffered a short period of apnoea, but they soon regained their normal breathing. There was no regurgitation of 
the suspension, and there were no immediate postoperation deaths.

\section{DURATION OF EXPERIMENTS Tridymite}

One rat from the group of animals injected with $12.5 \mathrm{mg}$., two from the group injected with $25 \mathrm{mg}$., two from the $25 \mathrm{mg}$. electro-dialyzed group, and five from that with $50 \mathrm{mg}$. were lost by death or cannibalism. Because of this larger number of deaths in the last group (50 mg.), it was not possible to obtain equal days of survival in all animals. However, the killing of animals was so adjusted as to enable the lung pathology to be studied till the maximum degree of fibrosis was produced by the different amounts of dust used. With the smallest dose $(12.5 \mathrm{mg}$.) the experiment extended to 300 days, with the $25 \mathrm{mg}$. doses to 100 days, and with the largest dose $(50 \mathrm{mg}$.) for only 75 days as none of the animals survived beyond that time.

\section{Coal + Tridymite}

Of the 18 animals in each of these five groups, several died, and of the rest two from each group were killed at $90,180,240,300$, and 330 days. All surviving animals were killed at 350 days.

\section{PATHOLOGICAL TECHNIQUE}

Routine post-mortem examinations were carried out on dead and killed animals. Formol-saline $(10 \%)$ was injected into the lungs before opening the thoracic cavity in animals which were killed, or in those which were found dead the lungs were distended with fixative after their removal from the thoracic cavity. After preliminary fixation blocks were selected through the long axes of both lungs at the level of the hilum, to include the hilar lymph nodes, for histological sections. Blocks were embedded in paraffin and sectioned at $5 \mu$. Serial sections were stained with haematoxylin and eosin, and by Gordon and Sweets' (1936) silver impregnation method; and micro-incineration was carried out to study the distribution of dust in the lesions. The details of these procedures have been fully recorded in earlier papers in this series. The lymph nodes were dissected and weighed as described by Nagelschmidt, Nelson, King, and Harrison (1954).

\section{COLLAGEN ESTIMATIONS}

For the estimations of collagen, the remaining lung tissue from each animal was dried at $105^{\circ} \mathrm{C}$., and to it was added the unused tissue from the blocks and trimmings which were dewaxed with xylene. The combined dried tissue of each lung was powdered in an iron mortar, re-dried at $105^{\circ} \mathrm{C}$., ground again and carefully mixed.

The collagen estimation depends upon the colorimetric determination of hydroxyproline, the most characteristic amino-acid of collagen and reticulin. The collagen is first transformed into gelatin by autoclaving a sample of the dried tissue. The proteins other than gelatin are precipitated by trichloroacetic acid and filtered off, the gelatin remaining in the filtrate. Hydro- lysis of the gelatin in a sample of the filtrate is carried out with hydrochloric acid to liberate the constituent amino-acids, and the hydroxyproline is then determined colorimetrically. The details of this procedure are given by Stacy and King (1954).

\section{RESULTS WITH TRIDYMITE}

\section{Gross Appearance of the Lungs}

$12.5 \mathrm{mg}$. Tridymite.-Animals in this group showed some scattered subpleural collections of dust in the early stages. These were greyish-white and most of them were seen over the dorsal aspects of the lung. Small discrete areas of fibrosis were seen over both lungs at 90 days, and these appeared larger at 150 days. There was little change from this time until 300 days, when the lung of one animal showed some confluent areas of fibrosis, and the others only patchy fibrosis.

25 mg. Tridymite.-There were subpleural dust collections of well-marked fibrotic areas dorsally at 30 days, and these became confluent by 60 days.

$25 \mathrm{mg}$. Electro-dialyzed Tridymite.-An animal was killed at nine days, and its lungs showed the same subpleural dust collections and a few definite areas of fibrosis. As early as 15 days the fibrotic areas were beginning to become confluent, and by 45 days these confluent areas were larger. A considerable part of the lung tissue was replaced by confluent fibrosis at $\mathbf{7 5}$ days, and this was still more marked at 105 days, when all the animals had died or been killed.

$50 \mathrm{mg}$. Tridymite.-Within the first week five animals died. Their lungs were haemorrhagic and parts were consolidated. The animal killed at 15 days had subpleural dust collections dorsally, with discrete areas of fibrosis. The areas of fibrosis were more numerous and more marked at $\mathbf{3 0}$ days, and the lungs of the animal dead at 50 days showed confluent fibrosis in both lungs. The last two animals died at 72 days and their lungs showed massive confluent fibrosis with very little lung tissue of normal appearance left.

The tracheo-bronchial lymph nodes in all these groups were enlarged to several times the normal size and were firm, and even hard in the case of animals killed late in the experiments.

\section{Histological Findings}

The lesions produced by the various amounts of tridymite were similar and the type of reaction differed only in the degree of severity. The smallest amount $(12.5 \mathrm{mg}$.) produced considerable fibrosis at 30 days, progressing to grade 3 at 60 days, grade 4 at 150 days, and the maximum 
fibrosis (grade 5) at 300 days. The $25 \mathrm{mg}$. dose produced fibrosis more rapidly, reaching the maximum at 60 days. There was hardly any difference between the reactions produced by the $25 \mathrm{mg}$. of tridymite, and the same quantity of electro-dialyzed tridymite. The most marked lesions were in the lungs of the animals which received the $50 \mathrm{mg}$. dose : grade 3 was reached by 30 days and grade 5 fibrosis at 50 days, involving nearly all the lung tissue. In all groups, subpleural drift of dust was seen microscopically, and the pleura overlying the lesions showed thickening. Dust cells were present in some alveoli, in the interstitial tissues and lymphoid follicles. There was marked hyperplasia of the peribronchial lymphoid tissues.

$12.5 \mathrm{mg}$. Tridymite.-At 30 days there was a good dust cell reaction and a marked peribronchial lymphoid reaction. Aggregates of dust cells contained a loose network of fine reticulin fibres (Fig. 1). Only an occasional nodule showed a small amount of collagen. The lesions were nodular and discrete at 60 days and the loose reticulin network was replaced by collagen fibres which were compact (grade 3 fibrosis, Fig. 2). The lesions were larger at 150 days, and almost completely acellular (grade 4 fibrosis). There was little change after this until 300 days, except that some areas of fibrosis became confluent (grade 5).

25 mg. Tridymite.-There was a good dust cell reaction at 30 days, and there were many discrete cellular lesions perivascularly distributed with thick and compact reticulin fibres, and some collagen in many of them (grade 2 fibrosis, Fig. 3). The lesions progressed so rapidly that by 60 days the nodules were mainly acellular, confluent, and collagenous (grade 5 fibrosis, Fig. 4), About half the lung area appeared to be replaced by confluent fibrosis. At 90 , 97 , and 110 days there was progressively less nonfibrous tissue remaining, and there was some pleural thickening.

$25 \mathrm{mg}$. Electro-dialyzed Tridymite.-The histological picture was very similar to that seen with the $25 \mathrm{mg}$. of undialyzed tridymite. Reticulin nodules were found as early as nine days (grade 2 fibrosis), and at 15 days nodules were largely acellular and collagenous (grade 3 fibrosis); similarly at 30 days. By 45 days the lesions were nearly all confluent, acellular and fully collagenous (grade 5 fibrosis). By the end of the experiment there was very little lung tissue uninvolved by fibrosis, and the pleura was also involved.

$50 \mathrm{mg}$. Tridymite.-During the first week five animals died, and their lungs showed varying degrees of pneumonic consolidation. In the lungs of an animal killed at 15 days there was good dust cell reaction, marked peribronchial lymphoid reaction, and many nodular lesions which were discrete, cellular, and composed of coarse, compact reticulin with a little collagen (grade 2 fibrosis, Fig. 5). At 30 days the nodules were discrete, larger, and somewhat acellular and collagenous (grade 3 fibrosis). At 50 days the right lung of an animal found dead was almost fully composed of large confluent areas of fibrosis which were acellular and fully collagenous (grade 5 fibrosis, Fig. 6). There was more alveolar tissue remaining in the left lung. All remaining animals in this group had died by 72 days, and in all there was almost total replacement and massive confluent fibrosis of the alveolar tissue of both lungs.

The histological findings in the lungs of the rats receiving the different dosages of tridymite are set out in Table 3 and Fig. 7. The data for $50 \mathrm{mg}$. of

TABLE 3

SUMMARY OF PATHOLOGICAL CHANGES IN LUNGS OF RATS PRODUCED BY VARIABLE AMOUNTS OF TRIDYMITE

\begin{tabular}{|c|c|c|c|c|c|c|c|c|}
\hline \multirow{2}{*}{$\begin{array}{l}\text { Days of } \\
\text { Survival }\end{array}$} & \multicolumn{2}{|c|}{$12.5 \mathrm{mg}$. } & \multicolumn{2}{|c|}{$25 \mathrm{mg}$. } & \multicolumn{2}{|c|}{$25 \mathrm{mg}$. (electro-dialyzed) } & \multicolumn{2}{|c|}{$50 \mathrm{mg}$. } \\
\hline & $\begin{array}{c}\text { Mode of } \\
\text { Death }\end{array}$ & $\begin{array}{l}\text { Grade of } \\
\text { Fibrosis }\end{array}$ & $\begin{array}{c}\text { Mode of } \\
\text { Death }\end{array}$ & $\begin{array}{l}\text { Grade of } \\
\text { Fibrosis }\end{array}$ & $\begin{array}{c}\text { Mode of } \\
\text { Death }\end{array}$ & $\begin{array}{c}\text { Grade of } \\
\text { Fibrosis }\end{array}$ & $\begin{array}{c}\text { Mode of } \\
\text { Death }\end{array}$ & $\begin{array}{c}\text { Grade of } \\
\text { Fibrosis }\end{array}$ \\
\hline $\begin{array}{c}1-9 \\
10-15 \\
16-30 \\
31-45 \\
46-60\end{array}$ & $\begin{array}{l}\overline{\bar{C}} \\
\text { Killed (1)* } \\
\text { Killed (1) }\end{array}$ & $\frac{-}{\frac{1}{3}}$ & $\begin{array}{l}\text { Died (1) } \\
\text { Died (1) } \\
\text { Killed (1) } \\
\text { Died (1) } \\
\text { Killed (1) }\end{array}$ & $\frac{-}{\frac{2}{5}}$ & $\begin{array}{l}\text { Killed (1) } \\
\text { Killed (1) } \\
\text { Killed (1) } \\
\text { Killed (1) } \\
\text { Killed (1) } \\
\text { Eaten (2) }\end{array}$ & $\begin{array}{l}2 \\
2 \text { max. } \dagger \\
3 \text { max. } \\
5 \\
5\end{array}$ & $\begin{array}{l}\text { Died (5) } \\
\text { Killed (1) } \\
\text { Killed (1) } \\
\text { Died (1) }\end{array}$ & $\begin{array}{l}\frac{\pi}{3} \max . \\
\frac{5}{5}\end{array}$ \\
\hline $\begin{array}{l}61-75 \\
76-90 \\
91-100\end{array}$ & Killed (1) & $\frac{-}{3}$ & Killed (1) & 5 & $\begin{array}{l}\text { Killed (1) } \\
\text { Killed (1) }\end{array}$ & $\begin{array}{r}5 \\
5 \\
\end{array}$ & Died (2) & $\frac{5}{-}$ \\
\hline $\begin{array}{r}91-100 \\
101-120\end{array}$ & Killed (1) & $\overline{3}$ & $\begin{array}{l}\text { Died (3) } \\
\text { Died (1) }\end{array}$ & $\begin{array}{l}5 \\
5\end{array}$ & Killed (1) & $\overline{5}$ & 二 & $\bar{z}$ \\
\hline $121-180$ & Killed (2) & $\begin{array}{l}4 \\
4\end{array}$ & - & - & - & - & - & - \\
\hline $181-299$ & $\begin{array}{l}\text { Killed (2) } \\
\text { Eaten (1) }\end{array}$ & & - & & - & - & - & - \\
\hline 300 & Killed (1) & 5 & - & - & - & - & - & - \\
\hline
\end{tabular}

* Numbers in brackets indicate the number of animals killed or found dead during that period. † Max. = Maximal within the grade of fibrosis. 

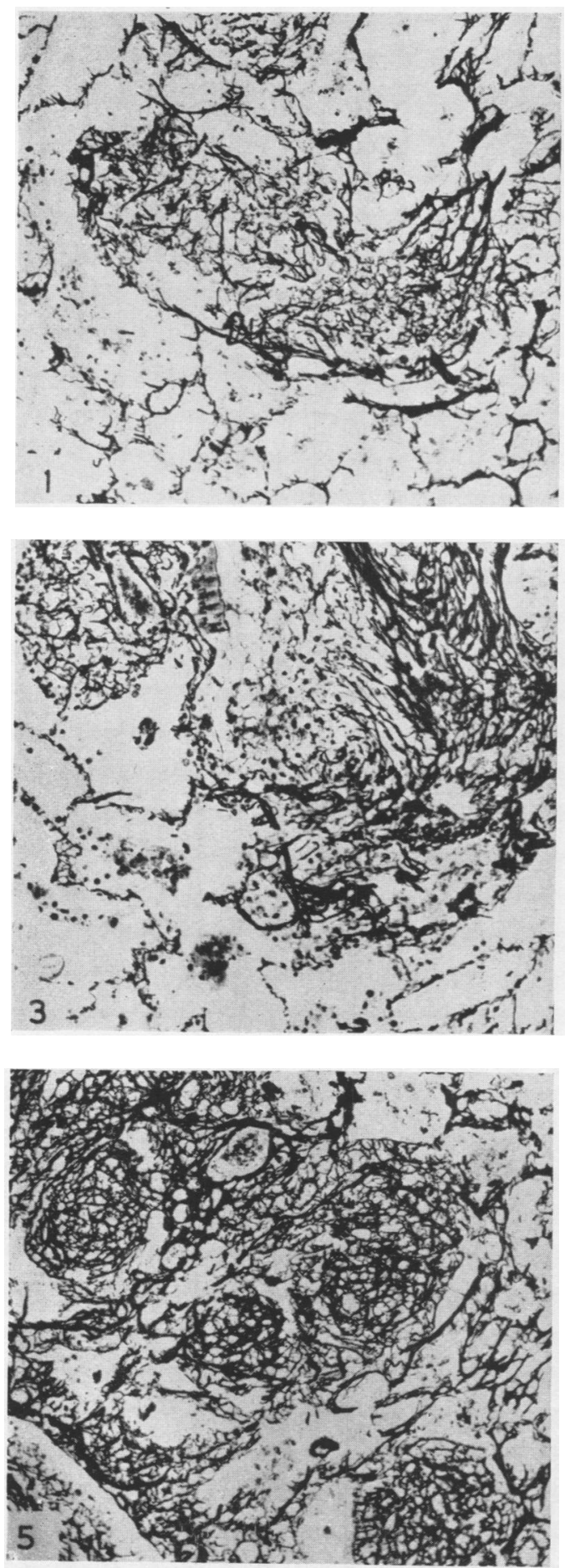

Fig. 1.-Rat lung 30 days after injection of $12.5 \mathrm{mg}$. tridymite. Nodular lesions showing a loose network of fine reticulin fibres (grade 1 fibrosis). Silver impregnation. $\times 210$.

Fig. 2.-Rat lung 60 days after injection of $12.5 \mathrm{mg}$. tridymite. Silicotic nodule with thick, compact collagen (grade 3 fibrosis). Silver impregnation. $\times 65$.

Fig. 3.-Rat lung 30 days after injection of $25 \mathrm{mg}$. tridymite. Nodular lesions with thick and compact reticulin and some collagen (grade 2 fibrosis). Silver impregnation. $\times 210$.


Fig. 4.-Rat lung 60 days after injection of $25 \mathrm{mg}$. tridymite. Confluent, fully collagenous lesions (grade 5 fibrosis) with a few patent alveoli. Silver impregnation. $\times 48$.

Fig. 5.-Rat lung 15 days after injection of $50 \mathrm{mg}$. of tridymite. Lesions show thick, compact reticulin and some collagen (grade 2 fibrosis). Silver impregnation. $\times 210$.

Fig. 6.-Rat lung 50 days after injection of $50 \mathrm{mg}$ tridymite. Confluent lesions with dense collagen (grade 5 fibrosis). A few patent alveoli and blood vessels seen within the lesions. Silver impregnation. $\times 48$. 


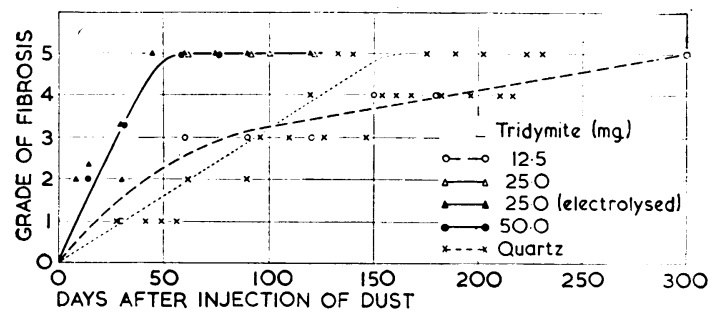

FIG. 7.-Grade of fibrosis of the lungs of rats after injection of different amounts of tridymite and $50 \mathrm{mg}$. of quartz.

quartz are taken from the controls of the cortisone experiment (Harrison, King, Dale, and Sichel, 1952).

\section{Collagen}

Collagen determinations from three of the four groups (omitting the $25 \mathrm{mg}$. tridymite not electrodialyzed) were made on the lungs of rats killed at monthly intervals. There was an increase with time and with the amount of tridymite administered. These results are set out graphically (Fig. 14). Data from Stacy and King (1954) for $50 \mathrm{mg}$. of quartz of similar size to the tridymite are added for
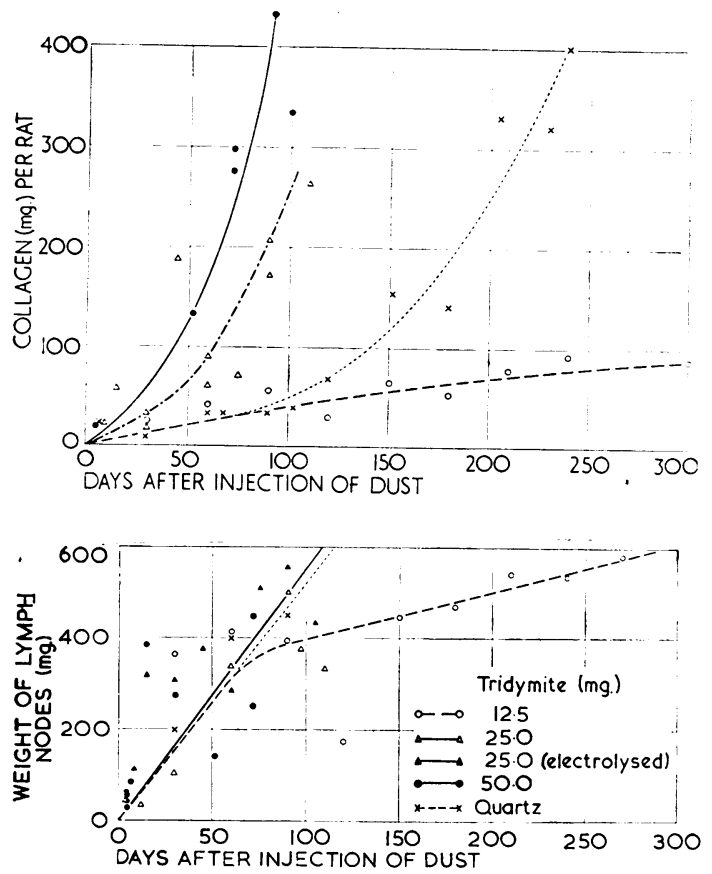

Fig. 14.-Collagen (mg.) in lungs of rats after injection of different amounts of tridymite and $50 \mathrm{mg}$. of quartz.

FIG. 15.-Weight of lymph nodes of rats after injection of different amounts of tridymite and $50 \mathrm{mg}$. of quartz. comparison. As some of the quartz collagen figures were erratic, mean results of 150 and 154 days and of 202 and 210 days were used for plotting. Fig. 14 shows a remarkable increase in the amount of collagen with the largest dose, and a reasonably good relationship between collagen production and tridymite administered up to 70 days when all animals in the $50 \mathrm{mg}$. tridymite group were dead or killed. The curve for collagen development in the quartz experiment is near that for the $12.5 \mathrm{mg}$. tridymite group for the first three months, but it rises more steeply later on and reaches after eight months the same high values as $50 \mathrm{mg}$. tridymite gave after three months.

\section{Development of Lymph Nodes}

After injection of quartz or flint, an abnormal swelling of lymph nodes of rats was observed (Nagelschmidt and others, 1954). The fresh weights of the lymph nodes from the four tridymite groups were determined and are shown in comparison with similar results for $50 \mathrm{mg}$. of quartz in Fig. 15. The quartz data were taken from the controls of the cortisone experiment (Stacy and King, 1954). Although there is a large scatter for individual results, Fig. 15 suggests that for the first 90 days neither amount of tridymite nor type of silica modification has any effect on the results. For longer periods of time the weights of the glands of animals with $12.5 \mathrm{mg}$. of tridymite were far smaller than those with quartz found by Stacy and King. No animals with higher tridymite doses survived for more than 120 days.

\section{RESULTS WITH COAL + TRIDYMITE}

\section{Gross Appearances of the Lungs}

$30 \mathrm{mg}$. Anthracite Coal and $30 \mathrm{mg}$. Bituminous Coal.-The gross appearances in the two groups were similar. There were collections of dust distributed diffusely over the lung surfaces at 90 days. By 180 days these seemed to be denser ; there were no further changes either at 300 or 350 days. The hilar lymph nodes were enlarged and black.

$30 \mathrm{mg}$. Anthracite $+1 \mathrm{mg}$. Tridymite and $30 \mathrm{mg}$. Bituminous +1 mg. Tridymite. - The lungs in these two groups were also very similar. At 90 days there were diffuse deposits of coal dust on the lung surfaces. The collections were larger at 180 days, and small white areas 2 to $3 \mathrm{~mm}$. in diameter were seen associated with them. No other changes, beyond a few pleural adhesions, were visible macroscopically from this time until 350 days. The hilar nodes were somewhat enlarged and black.

1 mg. Tridymite.-In the majority of the lungs there were no visible macroscopic changes at any 

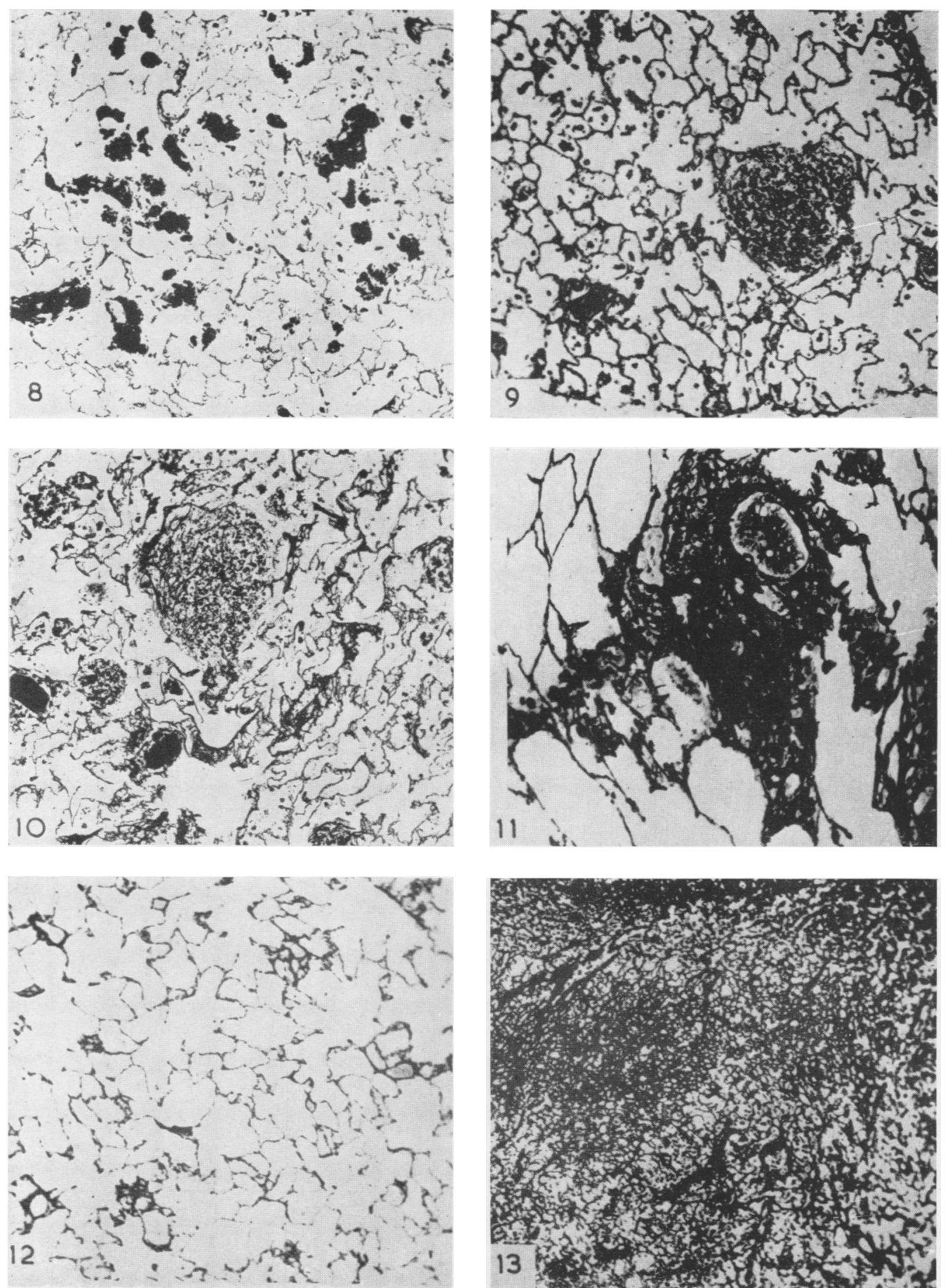

Fig. 8.-Rat lung 90 days after the injection of $30 \mathrm{mg}$. anthracite coal. Dust gathered into compact nodules without any fibrosis. Silver impregnation. $\times 120$.

Fig. 9.-Rat lung 90 days after the injection of $30 \mathrm{mg}$. anthracite coal and $1 \mathrm{mg}$. tridymite. Nodular dust collections with a few fine reticulin fibres arranged loosely (grade 1 fibrosis, min.). Silver impregnation. $\times 120$.

Fig. 10.-Rat lung 90 days after injection of $30 \mathrm{mg}$. bituminous coal and $1 \mathrm{mg}$. tridymite. Nodular lesions composed of dust with a loose network of reticulin fibres (grade 1 fibrosis). Silver impregnation. $\times 120$.

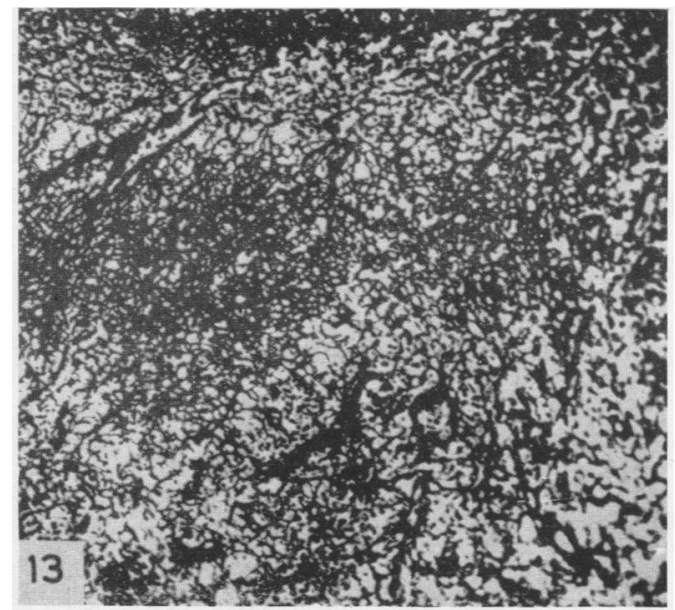

Fig. 11.-Rat lung 300 days after injection of $30 \mathrm{mg}$. bituminous coal and $1 \mathrm{mg}$. tridymite. Dust lesion adjacent to a blood vessel and containing thick and compact reticulin with some collagen (grade 2 fibrosis). Silver impregnation. $\times 160$.

Fig. 12.-Lung field from same rat as in Fig. 13. 300 days after injection of $1 \mathrm{mg}$. tridymite. There are no dust collections and there is no fibrosis. Silver impregnation. $\times 120$.

Fig. 13.-Hilar lymph node of same rat as Fig. 12. Loose network of thick reticulin fibres (grade 1 fibrosis max.). Silver impregnation. $\times 160$. 
period; but in a few there were small, discrete, white areas scattered over both lung surfaces. The hilar nodes were enlarged and firm.

\section{Histological Findings}

$30 \mathrm{mg}$. Anthracite and $30 \mathrm{mg}$. Bituminous Coal.The histological appearances of the lungs in these two groups were similar. At 90 days there was some dust lying free in the alveoli ; most of it was collected together in the form of irregular foci situated perivascularly. There was no evidence of fibrosis (Fig. 8). A mild degree of emphysema was present around the nodules, and there was hyperplasia of the peribronchial lymphoid tissues with dust in them. There was no change in the histological appearances of the coal dust lesions up to 350 days, except for the dust collections becoming more compact. No fibrosis was seen at any stage, either in the lungs or in the lymph nodes.

30 mg. Anthracite +1 mg. Tridymite.-At 90 days most of the dust was collected into irregular nodular lesions which were cellular and mainly perivascular. A few were subpleural. A mild degree of focal emphysema was present. The lesions contained loose reticulin fibres (grade 1 fibrosis, Fig. 9). By 180 days the dust lesions were more compact and the reticulin fibres were thicker. There was marked peribronchial fibrosis. There were many irregular, discrete nodules with thick and compact reticulin (grade 2 fibrosis) at 240 days ; but there was not much progress beyond this, the lesions remaining within the maximal limits of grade 2 fibrosis at $\mathbf{3 0 0}$ days and at $\mathbf{3 5 0}$ days. The lymph nodes showed only mild reticulinosis.

$30 \mathrm{mg}$. Bituminous $+1 \mathrm{mg}$. Tridymite.-There was a small amount of dust lying free in the alveoli at $\mathbf{9 0}$ days, but the greater part of it was in focal aggregations situated perivascularly. There was a - fine network of reticulin fibrils within the lesions (grade 1 fibrosis, Fig. 10). There was marked peribronchial fibrosis and some emphysema. There was no further progress until 240 days, when the nodules appeared to be more compact with thick reticulin fibres (grade 2 fibrosis). There was marked peribronchial fibrosis and some emphysema. By 240 days the nodules appeared to be more compact with thick reticulin fibres (grade 2 fibrosis). The lesions remained within the limits of grade 2 fibrosis at 300 days (Fig. 11), and had not progressed further by 350 days. Mild reticulinosis of the lymph nodes was seen at 300 days and 350 days.

$1 \mathrm{mg}$. Tridymite.-A very few focal aggregations of dust cells were seen in the lungs at 90 days, but there was no fibrosis. By 180 days some peribronchial fibrosis was seen, but there was no fibrosis in the few dust cell collections, although some fibrosis was evident in areas where such lesions were associated with bronchiectatic changes. Apart from this, no fibrosis was found in the lungs at any period up to 350 days.

The hilar lymph nodes contained some dust at 90 days, and by 300 days there were definite lesions which contained a loose network of thick reticulin fibres (grade 1 fibrosis, maximal, Fig. 13), whereas the lungs at this same period revealed no lesions whatever (Fig. 12).

A summary of the pathological changes in the lungs of rats produced by coal and tridymite alone and in combination is given in Table 4.

\section{DISCUSSION \\ Tridymite}

The tridymite used in these experiments produced very rapidly developing fibrosis in the lungs of rats, as compared with other forms of pure silica, which had been used in previous experiments. King and others (1953a) had found that $50 \mathrm{mg}$. of tridymite produced far more reaction in the lungs

TABLE 4

SUMMARY OF PATHOLOGICAL CHANGES IN THE LUNGS OF RATS PRODUCED BY COAL AND TRIDYMITE ALONE AND IN COMBINATION

\begin{tabular}{|c|c|c|c|c|c|c|c|c|c|c|}
\hline \multirow{2}{*}{$\begin{array}{l}\text { Days of } \\
\text { Survival }\end{array}$} & \multicolumn{2}{|c|}{ Anthracite $30 \mathrm{mg}$. } & \multicolumn{2}{|c|}{$\begin{array}{l}\text { Anthracite } 30 \mathrm{mg} \text {. } \\
+ \text { Tridymite } 1 \mathrm{mg} .\end{array}$} & \multicolumn{2}{|c|}{ Bituminous $30 \mathrm{mg}$. } & \multicolumn{2}{|c|}{$\begin{array}{l}\text { Bit uminous } 30 \mathrm{mg} \text {. } \\
\text { + Tridymite } 1 \mathrm{mg} \text {. }\end{array}$} & \multicolumn{2}{|c|}{ Tridymite $1 \mathrm{mg}}$. \\
\hline & $\begin{array}{l}\text { Mode of } \\
\text { Death }\end{array}$ & $\begin{array}{l}\text { Grade of } \\
\text { Fibrosis }\end{array}$ & $\begin{array}{l}\text { Mode -of } \\
\text { Death }\end{array}$ & $\begin{array}{l}\text { Grade of } \\
\text { Fibrosis }\end{array}$ & $\begin{array}{l}\text { Mode of } \\
\text { Death }\end{array}$ & $\begin{array}{l}\text { Grade of } \\
\text { Fibrosis }\end{array}$ & $\begin{array}{l}\text { Mode of } \\
\text { Death }\end{array}$ & $\begin{array}{l}\text { Grade of } \\
\text { Fibrosis }\end{array}$ & $\begin{array}{l}\text { Mode of } \\
\text { Death }\end{array}$ & $\begin{array}{c}\text { Grade of } \\
\text { Fibrosis }\end{array}$ \\
\hline $\begin{array}{c}1-90 \\
91-180 \\
181-240 \\
241-300 \\
301-350\end{array}$ & \begin{tabular}{l} 
Died (2)* \\
Killed (2) \\
- \\
Killed (2) \\
Died (1) \\
Killed (3) \\
Killed (2) \\
Killed (8) \\
\multicolumn{1}{c}{ - }
\end{tabular} & $\frac{\frac{0}{0}}{\frac{0}{0}}$ & $\begin{array}{l}\text { Died (2) } \\
\text { Killed (2) } \\
\text { Died (4) } \\
\text { Killed (2) } \\
\text { Died (1) } \\
\text { Killed (2) } \\
\text { Died (1) } \\
\text { Killed (2) } \\
\text { Died (1) } \\
\text { Killed (1) }\end{array}$ & $1 \frac{\overline{\min } .}{\frac{1}{2}}$ & $\begin{array}{l}\text { Killed (2) } \\
\text { Died (1) } \\
\text { Killed (3) } \\
\text { Killed (2) } \\
\text { Killed (2) } \\
\text { Killed (8) }\end{array}$ & $\frac{\frac{0}{0}}{\frac{0}{0}} \frac{0}{0}$ & $\begin{array}{l}\text { Died (3) } \\
\text { Killed (2) } \\
\text { Died (1) } \\
\text { Killed (2) } \\
\text { Killed (2) } \\
\text { Killed (2) } \\
\text { Died (1) } \\
\text { Killed (5) }\end{array}$ & $2 \frac{\frac{1}{1}}{\frac{\min }{\frac{2}{2}}}+$ & $\begin{array}{l}\text { Died (1) } \\
\text { Killed (2) } \\
\text { Killed (2) } \\
\text { Killed (2) } \\
\text { Killed (2) } \\
\text { Killed (9) }\end{array}$ & $\frac{\frac{0}{0}}{\frac{0}{0}}$ \\
\hline
\end{tabular}

* Numbers in brackets indicate the number of animals killed or found dead during that period. $\dagger$ Min. $=$ Minimal within the stated grade. 
of rats than the same amount of the other forms of pure silica-amorphous vitreous silica, quartz, and cristobalite. All these silica modifications were of the same high purity, i.e., about $99 \% \mathrm{SiO}_{2}$, the same particle size, and silica solubility. In that experiment tridymite produced fully collagenous confluent fibrosis in 60 days as compared with 270 days for quartz. In the present experiments the same dose of tridymite, $50 \mathrm{mg}$., acted similarly and produced the same degree and amount of fibrosis in about the same time, i.e., 50 days. A quarter of the amount $(12.5 \mathrm{mg}$.) produced similar lesions in 300 days, which is a little longer than the time taken by $50 \mathrm{mg}$. of quartz.

We had thought that the results of the previous animal tests with tridymite might partly be due to the presence of traces of hydrofluoric acid, although we could not demonstrate this chemically. The dust used here had never been in contact with hydrofluoric acid. Nevertheless, it seemed advisable to subject a sample of it to electro-dialysis to make certain of the elimination of any possible adsorbed ions. The severity of the fibrosis was not lessened by this treatment, and there seems no doubt that the extremely rapid and severe fibrosis is due to tridymite itself.

The results of the collagen estimations confirm the conclusions of the histological examinations, and give the possibility of an added, quantitative assessment of fibrosis, which it has not been possible satisfactorily to achieve by histological means. The histology of silicosis is essentially a qualitative matter. It reveals the nature of the lesions, the distribution and progress of the fibrosis and its severity, but it gives only a rough idea of the total amount of fibrosis present in a tissue. The collagen estimations, in conjunction with the histological examinations, have the advantage of enabling us to say not only what sort of fibrosis is present, but how much of it there is. The curves in Fig. 14 show that collagen production takes place at a steady rate with the $12.5 \mathrm{mg}$. dose of tridymite. Approximately 0.8 to $1.2 \mathrm{mg}$. of collagen is produced per month per mg. of tridymite, which has $23 \mathrm{~cm}^{2}$. of surface.

The curves for quartz and for the higher tridymite levels do not appear to be straight lines. The data are not sufficient in number and they are too erratic to warrant a detailed discussion, but they suggest that the rate of collagen production for both higher tridymite levels is the same and is about twice as high as that for the lowest level.

Fifty milligrams of quartz appear to produce only $0.34 \mathrm{mg}$. of collagen per mg. of quartz per month during the first four months, but the rate is nearly five times as high, namely $1.6 \mathrm{mg}$. of collagen, for the next four months. Further work is required to confirm these early impressions.

The reason for the higher rate of collagen production by tridymite as compared with quartz is still entirely unknown. The difference does not appear to be related to silica solubility and this leaves surface characteristics or crystal structure as possible alternatives.

\section{Coal + Tridymite}

The results with anthracite and bituminous coal dusts confirm those of previous experiments that no fibrosis was produced by coal dust in the lungs of animals. The only histological change observed during the course of the experiment was a gradual sweeping of the injected coal particles into focal accumulations of dust deposits. The $1 \mathrm{mg}$. of tridymite used alone likewise caused no fibrosis in the lungs. Pulmonary infection was found in the lungs of one animal which died, and there was fibrosis associated with the infective lesions. But the results in the remaining animals were uncomplicated by infection, and no lesions were demonstrated in the lungs of any of the animals, although some fibrosis was demonstrated in the hilar lymph nodes at $\mathbf{3 0 0}$ days and $\mathbf{3 5 0}$ days. This is probably due to the small amount of tridymite dust being removed from the lungs to the lymph nodes before any pulmonary fibrosis occurs. Ray and others (1951) obtained similar results with $2 \mathrm{mg}$. of quartz.

When the same quantity of tridymite $(1 \mathrm{mg}$.) was injected together with anthracite or bituminous coal in $30 \mathrm{mg}$. doses, definite pulmonary lesions were produced. Reticulin fibrosis of grade 1 was observed at 90 days, and of grade 2 by 240 days in both groups. The lesions advanced only slightly beyond this stage, remaining within the maximal limits of grade 2 at 300 and 350 days. It is likely that the inert coal retards the movement of tridymite in the lymphatics causing it to be retained in the lungs where it exerts a fibrogenic effect. With a much higher percentage $(20 \%)$ of quartz used with coal-mine dust Belt and King (1945) observed grade 4 fibrosis at 365 days, and Ray and others (1951) grade 3 fibrosis when $2 \mathrm{mg}$. of quartz was used with $98 \mathrm{mg}$. of coal. The smaller amounts of tridymite (1 mg.) and coal $(30 \mathrm{mg}$.) used in these experiments produced grade 2 fibrosis when injected in combination.

No differences were observed between anthracite and bituminous coal when used with tridymite or alone. Neither coal appeared to act as an antidotal dust when used with free silica in animals. On the other hand they appeared to enhance the effect of small amounts of silica by keeping it in the lungs. 


\section{SUMMARY}

Different amounts of pure tridymite dust of equal particle size, injected into the lungs of rats, produced the maximum degree of fibrosis in 300 days with $12.5 \mathrm{mg}$. of tridymite, in 60 to 70 days with $25 \mathrm{mg}$., and in 50 days with $50 \mathrm{mg}$. With the $50 \mathrm{mg}$. dose most of the lung tissue was replaced by fibrous areas. Chemical determinations of collagen demonstrated both a more rapid and a larger total production of fibrous tissue with the larger doses of tridymite. Tridymite, $12.5 \mathrm{mg}$., caused, during the first three months, the production of as much collagen as $50 \mathrm{mg}$. of quartz, but produced after eight months only one quarter of the amount which 50 mg. of quartz gave. The quartz had then produced as much collagen as $50 \mathrm{mg}$. of tridymite in three months.

Mixtures of anthracite and bituminous coal dust with a small amount of tridymite $(1 \mathrm{mg}$.) produced lesions of grade 2 fibrosis in the lungs. Anthracite and bituminous coal by themselves did not produce any fibrosis in lungs or hilar lymph nodes in 350 days. Tridymite, $1 \mathrm{mg}$., appeared to be completely eliminated from the lungs into the hilar lymph nodes : fibrosis was observed in the lymph nodes, but none was found in the lungs.

The authors are indebted to the Medical Research Council for a grant towards the expenses of the investigation, to Mr. E. H. M. Badger, of the North Thames Gas Board laboratory, for supplying the tridymite, to Mr. B. D. Stacy for the collagen determinations, to Mr. J. Cartwright for the size distributions, to $\mathrm{Mr}$. B. C. S. Hollands for technical help with the animals and in the cutting and staining of sections, and to the Ministry of Fuel and Power for permission to publish.

\section{REFERENCES}

Belt, T. H., and King, E. J. (1945). Spec. Rep. Ser. med. Res. Coun., Lond., No. 250.

Gardner, L.' U. (1938a). Amer. Inst. Min. Met. Eng. Techn. Publ., No. 929.

1938b). In "Silicosis and Asbestosis", ed. Lanza, A. J. pp. 257-345. Oxford Univer. Press, New York.

pp. 257-345. Oxford Univer. Press, New York. 12545.

Gordon, H., and Sweets, H. H. (1936). Amer. J. Path., 12, S45. Harrison, C. V., King, E. J., Dale, J. C., and Siche
British Journal of Industrial Medicine, 9, 165.

King, E. J., Mohanty, G. P., Harrison, C. V., and Nagelschmidt, G. (1953a). Ibid., 10,9.

Nagelschmidt, G., Nelson, E. S., King, E. J., and Harrison, C. V. (1954). British Journal of Industrial Medicine, 11, 145.

Ray, S. C., King, E. J., and Harrison, C. V. (1951). Ibid., 8, 62. Stacy, B. D., and King, E. J. (1954). Ibid., 11, 192. 